\title{
Threats and opportunities for post-closure development in dolomitic gold mining areas of the West Rand and Far West Rand (South Africa) - a hydraulic view Part 3: Planning and uncertainty - lessons from history
}

\author{
EJ (Leslie) Stoch* and Frank Winde \\ North West University, Potchefstroom Campus, Private Bag X6001, Potchefstroom, 2520, South Africa
}

\begin{abstract}
Mining is exposed to geological uncertainty as well as to economic forces beyond its control, such as commodity prices and exchange rates that govern profitability. Predictions of future scenarios in mining areas are thus inherently difficult and unreliable. This uncertainty is exacerbated by the long time periods required for pro-active planning of post-mining developments often spanning several decades. This paper presents examples from a gold mining area in the Far West Rand (South Africa) illustrating the variance between predicted scenarios and reality. The facts are embedded in a historical recount of events crucial for the design and approval of mine-closure plans, as well as post-mining development. It is argued that historical arrangements and data need to be understood and preserved in order to avoid the repetition of (costly) mistakes made in the Far West Rand. Owing to the pivotal role of water in the semi-arid area and the fact that some of the most important groundwater resources of South Africa were impacted on by deep-level mining, this paper in 3 parts adopted a largely hydraulic perspective. The loss of 'institutional memory' and local expertise has been identified as the main threat to planning. Part 3 presents an attempt to counteract such loss by providing an account of the events of 5 decades, as witnessed by the first author.
\end{abstract}

Keywords: gold mining, dolomitic compartments, dewatering, farming, post-mining developments

\section{Introduction}

Part 3 follows on from Parts 1 and 2, addressing the legacy inherited by, threats to, and opportunities for, future development of an area heavily impacted on by mining (Winde and Stoch, 2010a; b). In Parts 1 and 2 examples of the need to preserve what is termed 'institutional memory' were provided, in order to avoid repeating the mistakes of the past and to create a sound base for decisions regarding mine closure. Part 3 attempts to assess, in the case of the Far West Rand (FWR) goldfield, the extent to which the anticipated scenarios and predicted developments match reality. To this end historical planning documents have been analysed and compared with actual developments that have taken place. Again the focus is on the effects of mining on natural resources, with the emphasis on dolomitic groundwater. The approach acknowledges the particular challenges of planning for areas largely controlled by a volatile and rather unpredictable industry, which is not only subjected to geological uncertainty, but also exposed to global economic forces, such as the gold price and ZAR/USD exchange rates, operating beyond its control. Furthermore, the occurrence of drastic political changes in the recent past, at global and national scales, further supports the fact that planning horizons which spanned several decades are inherently plagued by uncertainty. However, in identifying areas of significant variance between expectation and reality, it is hoped that first approximations for quantifying uncertainty in mining-dominated environments can be derived and factored into current attempts to predict developments and plan for a sustainable future.

\footnotetext{
* To whom all correspondence should be addressed.

푤 +2718 299 1582; fax: +2718 2991582 ; e-mail: frank.winde@nwu.ac.za

Received 5 August 2009; accepted in revised form 9 December 2009.
}

\section{Historical development of mining and water-related issues in the FWR}

\section{The pre-mining period}

The recent history of the FWR is a lesson about changes taking place in many different fields - political, scientific, economic and demographic. Unfortunately, a simplistic arrangement does not apply to the FWR, where planning and serendipity appear to be major role players in roughly equal proportion. To this must be added the vagaries of politicians, industrialists, scientists and the community leaders involved, where the dominant drivers seem to have been financial- and/or self-interest.

The $1^{\text {st }}$ step to disturb what can be labelled an 'agrarian equilibrium', based on successful irrigation farming in the Wonderfonteinspruit (WFS) valley, was the indirect influence of mining that led to the large-scale pumping of dolomitic groundwater from the Zuurbekom Compartment - a major karst aquifer straddling the southern boundary of the upper WFS catchment. This water was supplied to Ferreira's Camp, a temporary mining site that grew in stature and size from 1886 to the present economic dynamo of global significance, Johannesburg (Ramsden, 1985). The large volumes pumped from the Zuurbekom Compartment soon led to the drying up of the source of the Klip River. Furthermore, many springs in the vicinity of the mining camp, for example Doornfontein and Turffontein, were contaminated by the horse stables and wash-houses placed adjacent to these water resources. These developments soon fuelled contention between the farmers dependent on the water and the Johannesburg Waterworks Estate and Exploration Company (Ramsden, 1985).

Although gold reefs were known to exist in the FWR, the Pullinger Brothers, using the technology available in 1910, 
failed to stem the ingress of water when they tried to sink the $1^{\text {st }}$ shaft at Venterspost. It was only after the François Cementation Process was successfully used in the East Rand that it became possible to mine through the dolomites of the Venterspost Compartment (Swart et al., 2003). Initially the cracks in the roofs of stopes were successfully grouted, but as mining progressed the sagging of the rocks resulted in new ruptures generating large volumes of ingressing water. In response the Venterspost Mine decided to sink surface wells and used largevolume pumps to drop the hydraulic head. The authorisation to remove water found in a mine was obtained from existing mining legislation. The associated discharge of the surplus water across the farm boundary was, however, illegal, contravening stipulations laid down during the Zuid-Afrikaanse Republiek (ZAR), including the Irrigation and Conservation of Waters Act No. 8 of 1912 and the subsequent declaration of the Area as a Subterranean Water Control Area in terms of Proclamation Nos. 68 and 69 of 1913.

The farmers dependent on the Venterspost Eye, who had, since the late 1930 s, received the pumped surplus water from the mine, apparently welcomed this augmentation of their irrigation resource. Perceptions changed, however, when the Venterspost Eye eventually ran dry in 1947, accompanied by a plague of sinkholes affecting a nearby farm in the dewatered area of the Wonderfonteinspruit (WFS), to such an extent that it was dubbed 'sinkhole farm'. Should history repeat itself, nothing will be done until the crisis of change looms for those unfortunate enough to inherit the legacy of mining and lack of precautionary planning.

The 'worst case scenario' would leave the FWR residents with major problems that could even impact on downstream municipalities, such as Potchefstroom (Tlokwe), falling well outside the actual mining area. While the FWR would face severe economic impacts, with a large proportion of employment opportunities being lost, Potchefstroom may suffer from extended water shortages when mining ceases, with some $100 \mathrm{M} \ell / \mathrm{d}$ less water available for between 15 and 60 years (Swart et al., 2003).

The FWR lies on the road between Taung, where the 'manapes' frolicked, and Kromdraai, claimed to be one of mankind's evolutionary nests. Common to this stretch of dolomitic karst is a temperate climate, often stated to be among the best in the world, overlying South Africa's premier aquifers. Humankind and its precursors have therefore been part of the FWR tapestry since the dawn of unrecorded history. The 1836 pre-settlement 'pen-picture' of the area as left by Captain Harris was of an:

'abundance of water ... boundless meads ... covered with luxuriant herbage and entrammelled with rich parterres of brilliant flowers ... animated by droves of portly elands, moving in a long procession across the silent and treeless landscape' (Ramsden, 1985).

This poetic description could form the baseline for the environmental purists who appear to resist change, and is clearly an unobtainable dream. The environment that supported "Mrs. Ples" was free of modern anthropogenic interference. It is interesting to note that stone-age implements were found at all the springs that cascaded down the WFS and that Boskop man - an early hominid - was apparently a 'regular visitor' at the Gerhard Minnebron watering hole (Dart, 1954). Therefore, it may come as no surprise that remains of digging tools used by San people were recovered from the WFS at Welverdiend, or that the ruins of Ghoya huts are still to be found in the area (Mauch, 1872). This peaceful panorama changed when the 'mfecana' (Tswana: the calamity), spread across Southern
Africa and did not leave the FWR untouched. The result of this substantial upheaval was a drastic change described in the evidence laid before the Inter-Colonial Commission: Mr. Tudor Gruffyd Trevor, the Acting Inspector of Mines, in his response to the question '(Is it) quite right that when the farmers came there was no population, but that was owing to the raids of the Zulus who killed off everybody?' replied 'That is so...' (Wessels et al., 1905). It therefore appears that before the settlers arrived, the Highveld was unpopulated (again). The Tswana must have returned at more or less the same time, soon to be followed by a band of prospectors and adventurers, which led to the establishment of the City of Johannesburg fed by the dolomitic spring at Zuurbekom, until water from the Vaal River could be relayed by the public utility, Rand Water.

\section{The mining period: pre-dewatering}

A detailed account of how mining in the FWR developed is provided in Winde and Stoch (2010b). Soon after mining commenced in the area it became clear that farming and mining interests were destined to clash over water. The inexorable result of financial pressure was that the content of the vast aquifers was deliberately pumped to waste, a decision that devastated the agricultural community. While the disastrous effects on the farming community were anticipated and taken into account when dewatering was permitted, other consequences were not, including increasing ground movements and the development of some catastrophic sinkholes. By the time permission was given to dewater the Bank Compartment (1969), it was an established fact that sinkholes would follow the drop in the water table, a connection previously denied. When mining ceases and the underground pumps are switched off, an intermediate period of water loss will follow as the mine voids and compartments recharge. Should the rise in water table be left to the vagaries of chance, the mines will escape the most important condition on which the right to dewater was based, i.e. that the full, normal flow of the dolomitic springs be restored, to be followed by yet another (possible) period of accelerated ground movement. The latter phenomenon was experienced at Venterspost and Westonaria during an unintended, partial rewatering period caused by a 'wet spell' in the mid-1970s, when old sinkholes were reactivated and new ones were formed.

Another unexpected by-product of mining is the unrivalled, vast store of data and information on karst hydrology, ground movement and pollution which North-West University has started to accumulate. Planning for the future would, undoubtedly, benefit from the more than 70 years of investigations and accumulated experience in the FWR to which the tag 'memory' has been attached. Unfortunately, much valuable information has already been lost and, if left untended, the remnants will soon follow.

A chain of gold mines in the FWR started with Venterspost in 1934, Libanon in 1936 and Blyvooruitzicht in 1937. Associated mining towns such as Venterspost, Westonaria and Blyvooruitzicht were proclaimed during the 1930s, under the auspices of the Peri-Urban Areas Board. Westonaria and Carletonville became municipalities in 1948 and 1959 respectively (Potgieter, 1978). Fochville, where a rail spur provided a once-per-week service from Potchefstroom, changed its status from a sleepy agricultural village to a modern 'platteland' town when sinkholes required Government to extend the railway line. This was in order to have an emergency by-pass of the Dolomitic area should sinkholes force the permanent closure of the existing Cape Town to Johannesburg railway line, built during the late 1890s across dolomitic land in the FWR. Fochville 
received a $2^{\text {nd }}$ boost when Anglo American decided to house its employees at Fochville rather than Carletonville for the same reason, i.e. the danger posed by sinkholes. These ad hoc 'changes' represent some of the more visible and unforeseen consequences of the 'uniform policy of dewatering' accepted by the Government of the day.

\section{The post-dewatering mining period}

The 1956 change in water-related legislation was to a large extent motivated by the events in the FWR area, where farmers had lost their irrigation water in 1947 (when the Venterspost Eye dried up) and now faced the same fate threatening the eye at Oberholzer, which at the time was the main water source for a vibrant community of irrigation farmers. The perceived threat resulted from the newly-established West Driefontein Gold Mine which, in response to rising volumes of water ingressing into its underground mine workings since 1952, had increased pumping at an alarming rate. The authority of the Governor-General was transferred to the Minister of Water Affairs who, within months, appointed an Inter-Departmental Committee (IDC) to investigate the impact of mining on the dolomitic compartments (Jordaan et al., 1960). The IDC appointment was in response to a request from the West Driefontein and Blyvooruitzicht Mines to supply water to the Oberholzer Irrigation Board (OIB), who, unlike the Venterspostloop Irrigation Board, refused to accept the mine discharge in lieu of their natural water supply (Jordaan et al., 1960). It soon transpired that the position at West Driefontein was vastly different from that experienced at Blyvooruitzicht, as the latter was a relatively dry mine that indeed had to purchase water from the OIB from 1938 to 1948. All pumped water at Blyvooruitzicht was returned to the dolomitic compartment from where it originated. West Driefontein, on the other hand, discharged some of the abstracted water into the veld, soon threatening the railway line some distance north of the mine. The debate on whether to allow the Oberholzer Compartment to be dewatered, as had occurred in the case of the Venterspost Compartment, was long and acrimonious with disagreement being registered between the Department of Water Affairs and the farmers on the one hand and the Department of Mines on the other. There was even disagreement as to the wisdom of an enforced policy of dewatering amongst the gold mines, with Blyvooruitzicht opposing dewatering and West Driefontein forcibly promoting it. It was upon the recommendations in the final report of the IDC that Government acceded to the request of Gold Fields of South Africa to dewater the Oberholzer Compartment, the damage having already been done in the Venterspost Compartment, without any authorisation (Jordaan et al., 1960). This and other important documents were withheld from the farmers, who were left at the mercy of a department that was aware of the fact that excessive pumping would lead to the drying up of the dolomitic springs (Jordaan et al.,1960; Wessels et al.,1905) and had informed the Minister that the flow from the Oberholzer Eye was failing (Enslin et al.,1958).

It does not do the Department of Water Affairs at the time any credit to have learned from the final report of the IDC that illegal dewatering was condoned, as the Oberholzer Eye was allowed to run dry in September 1959, and then base the argument in favour of dewatering on the fact that a point of no return had already been reached. Consequently Government suggested to the mining industry that a body should be established with the main aim of dealing with compensation claims of farmers suffering from dewatering-related damages. This body was the Far West Rand Dolomitic Water Association (FWRDWA), which formally adopted its constitution in November, 1964 (Haak,
1964). This arrangement was, stricto sensu, a profitable partnership between the State and the Chamber of Mines, as 2 organisations, with representation of both parties, were established to deal with the fallout of de-watering:

- One committee was responsible for the administration of the dewatering policy and its consequences to the 'small man', i.e. the Far West Rand Dolomitic Water Association (FWRDWA), chaired by the Chamber of Mines

- The other was a State Co-ordinating Technical Committee (SCTC) appointed by the Minister of Mines that would supply the expertise to advise the State and the FWRDWA on matters relating to ground movement and the management of water in the affected and neighbouring compartment. Hidden from the public for the most part was the fact that the State in fact provided approximately two-thirds of the FWRDWA budget and the entire budget of the SCTC (Enslin, 1963).

The agreement of 1964 made provision for the post-mine restoration of the natural water supply, by far the greatest sustainable asset of the FWR. The fact that the Environmental Management Plan (EMP) process initiated by the Department of Minerals and Energy in 1992 was mine-based, rather than a co-ordinated effort to manage a region, in retrospect, does not provide a platform of confidence. The status quo appears to be one where time has eroded the 'memory' of the conditions on which the dewatering policy was based, to the extent that an attempt was made to disband the FWRDWA and the SCTC seems to have fallen into a state of disrepair. The recent appointment of an array of 'new' interdepartmental committees appears to be of limited value, as the committee members have little or no idea of the original rules that had been laid down.

\section{Consequences for urban developments}

\section{Impacts of sinkhole-related land degradation}

Large tracts of land purchased by the FWRDWA, to which the State contributed via a special amendment to the Income Tax Act, have recently through poor management been transformed into slums invaded by what are colloquially referred to as 'squatters', a large percentage of whom are said to be illegal immigrants who are not gainfully employed.

Future planning for the area will need to take into consideration the militancy of an under-employed and largely unskilled community spread across various formal and informal settlements, along with the impact of HIV/AIDS, and balance this against the run-down agricultural legacy and the loss of water, even if polluted. Nearly 5 years after the Merafong City Local Municipality took the decision to evacuate parts of Khutsong because of sinkhole problems (at an estimated cost of ZAR1.5 bn.), building operations had not commenced. The present cost estimate is upward of ZAR2.2 bn. and continues to climb.

\section{Post-Mining Master Plan: Far West Rand (1978)}

The Property Division of Gold Fields of South Africa, arguably the largest single property holder on the FWR, carried out studies during 1975 and 1976, in connection with the post-mining future of their investment along what was known as the West Wits Line. The reason for these studies, more than likely, stems from the predictions in the final report of the IDC (Jordaan et al., 1960) that, of the 2 mines in the Venterspost Compartment, i.e. Venterspost and Libanon, the $1^{\text {st }}$ mine was expected to close in 1981 and the $2^{\text {nd }}$ in 1995; and that of the 2 mines in 
the Oberholzer Compartment, i.e. Blyvooruitzicht and West Driefontein, the $1^{\text {st }}$ mine would close during 1985 and the $2^{\text {nd }}$ by 1999 . There is little doubt that these predicted closure dates provided the motivation for establishing a steering committee that would develop a master plan for the West Wits Line region. The $1^{\text {st }}$ meeting took place on 10 February 1977 with a follow-up discussion during November 1976, an event that was attended by representatives of the FWRDWA, Gold Fields of South Africa and the Institute for Regional Planning. The master (development) plan was delivered in July 1978 (Potgieter, 1978). On 3 May 1983, when the designation of the Committee was changed to a 'Regional Development Association', it was agreed:

... 'that because the future development of the Far West Rand, particularly after mining in the area ceases, (would be) totally dependent on the amount and quality of the water available, and since the demands on the Vaal River System are already exceeding the abilities of that system with the result that the Far West Rand will have to rely on its own sources your Commission be requested to undertake an investigation to determine:

- the amount of water which can be obtained on a sustained basis from the Dolomitic compartments in the Wonderfontein Spruit catchment area; and

- the suitability of the water for various industrial and other urban uses.' (Steering Committee, 1983).

While it is not known whether an investigation was ever undertaken by the South African Water Research Commission (WRC), as no evidence thereof has been found to date, what needs to be emphasized is that the fore-knowledge existed that the availability of water, in terms of both quantity and quality, would be the main determining factor for sustainable development in the post-mining era. The predicted volumes of water to be pumped from the 2 dolomitic compartments, as set out by the IDC and compared with the actual volumes pumped by the respective mines, are given in Table 1.

From Table 1 it is clear that Jordaan et al. (1960) significantly underestimated the anticipated mine-closure dates, while the future pumping rates were over-estimated (by up to $400 \%$ ). The Venterspost pumping rate for 1995 was $17.2 \mathrm{M} \ell / \mathrm{d}$ and for Oberholzer $39.66 \mathrm{M} \ell / \mathrm{d}$. Both values are well below the long-term average of the pre-mining discharge of the eyes. It is interesting to note that, while deviations generally increase the expectations into the future, a threshold seemed to be reached at 15 years after the predictions were made. In this year (1975) the variance between predicted and actual pumping volumes for both compartments reached a maximum and was somewhat reduced thereafter. The Blyvooruitzicht Mine, which has threatened closure for the past 20 to 25 years, now claims an additional lifespan of around 20 years. Closure for Driefontein Consolidated, which includes the West Driefontein Mine, has been extended to 2050 with the result that approximately 40 years should be added before the eyes could be expected to flow once more.

The old Western Area Mine (located in the southern part of the Western Gemsbokfontein Compartment) which, for all practical purposes, had ceased underground operations some years ago and the No. 4 Shaft of which Harmony had been authorised by the Department of Minerals and Energy to cease pumping, has been revitalised in a different guise; $65 \mathrm{M} \ell / \mathrm{d}$ is consistently being pumped by the mine, whereas the natural spring, on average, delivered less than $10 \mathrm{M} / \mathrm{d}$. This large increase in volume is considered to be a substantial asset in a water-stressed region. Possible reasons for this considerable mismatch between premining spring-flow, which is seen as an indication for the natural water balance (Jordaan et al., 1960), and the current, much larger, pumping volumes, are discussed in Winde et al. (2006).

The predicted (and stipulated) restoration of the "normal flow' of the dried-up eyes was expected for 2042 for the Venterspost Eye and 2045 for the Oberholzer Eye (Jordaan et al.,1960). In the meantime both the Bank and BoskopTurffontein Compartments were, and are, being partially dewatered and the extra mine voids should be added to the aquifer capacity when calculating the time required to recharge the system. The impact of sinkholes which are directly connected to the cavernous karst needs to be factored into the calculations as well. The mines operating during the IDC tenure as listed by Jordaan et al. (1960) are listed in Table 2.

To this cluster must be added the East Driefontein, Deelkraal and Elandsrand Mines.

The Inaugural Meeting of the Steering Committee of the West Wits Line Regional Planning Scheme was attended by Gold Fields of South Africa Limited, the Far West Rand Dolomitic Water Association, the Regional Planning Institute of Potchefstroom University, the Department of Planning and Environment, as well as the Department of Local Government, as its founding members. Although the Minutes state that the objective of the FWRDWA was a '... possible return of the land to production and utilisation', it also states that the FWRDWA '... was not interested in establishing uneconomical farming units in an area that had abundant water under control of an irrigation board. Preliminary soil tests had been carried out in the area and confirmed that the Wonderfontein Valley was fertile' (Rafferty, 1977a).

The comment of the Steering Committee was based on work done by the Institute for Pedological Research of Potchefstroom University (now the North-West University), which used students to do the field work (Potgieter, 1978). Since not much value can be attached to this type of investigation (Stoch, 1976), if coupled to the selective membership of the Steering Committee, this questions the sincerity of the expressed intention of the industry members. In true dictatorial style, typical of the Government of the day, decisions were taken on behalf of the community, without any consultation. It

\begin{tabular}{|c|c|c|c|c|c|c|}
\hline \multicolumn{7}{|c|}{$\begin{array}{c}\text { Table } 1 \\
\text { Comparison between predicted and measured pumping rates }\end{array}$} \\
\hline Year & \multicolumn{2}{|c|}{$\begin{array}{l}\text { Predicted pumping rate (Me/d) } \\
\text { (Jordaan et al., 1960) }\end{array}$} & \multicolumn{2}{|c|}{$\begin{array}{l}\text { Actual pumping rate (Me/d) } \\
\text { (DWAF, 1986) }\end{array}$} & \multicolumn{2}{|c|}{ Difference $(\%$ of predicted rate $=100 \%)$} \\
\hline Eye $^{*}$ & $\begin{array}{l}\text { Venterspost } \\
20.9\end{array}$ & $\begin{array}{c}\text { Oberholzer } \\
54.1\end{array}$ & $\begin{array}{l}\text { Venterspost } \\
20.9\end{array}$ & $\begin{array}{l}\text { Oberholzer } \\
54.1\end{array}$ & Venterspost & Oberholzer \\
\hline 1960 & 64.6 & 140.0 & 54.0 & 147.1 & $84 \%$ & $105 \%$ \\
\hline 1970 & 66.8 & 215.9 & 36.3 & 81.8 & $54 \%$ & $38 \%$ \\
\hline 1975 & 69.1 & 222.8 & 33.3 & 56.7 & $48 \%$ & $25 \%$ \\
\hline 1985 & 71.4 & 225.0 & 38.8 & 58.6 & $54 \%$ & $26 \%$ \\
\hline
\end{tabular}

* Pre-mining average flow of natural karst springs (eyes) associated with the respective dolomitic compartments 


\begin{tabular}{|l|l|l|c|c|c|}
\hline \multicolumn{6}{|c|}{$\begin{array}{l}\text { Table 2 } \\
\text { Dates of selected gold mines starting to operate in the Far West Rand with dolomitic compartments } \\
\text { impacted on and volumes of groundwater abstracted (Data from Jordaan et al., 1960) }\end{array}$} \\
\hline Mine & $\begin{array}{l}\text { Dolomitic } \\
\text { compartment }\end{array}$ & $\begin{array}{l}\text { Overlap } \\
\text { compartment }\end{array}$ & $\begin{array}{c}\text { Average } \\
\text { pumping volume } \\
\text { (1959) Me/d }\end{array}$ & $\begin{array}{c}\text { Shaft sinking } \\
\text { commenced }\end{array}$ & $\begin{array}{c}\text { Developing } \\
\text { commenced }\end{array}$ \\
\hline Western Areas & Gemsbokfontein & & & 1959 & \\
\hline Venterspost & Venterspost & & 61.5 & 1935 & 1939 \\
\hline Libanon & Venterspost & Bank & 5.1 & 1936 & 1948 \\
\hline West Driefontein & Oberholzer & Bank & 84.1 & 1945 & 1952 \\
\hline Western Deep Levels & Oberholzer & Bank & & 1957 & \\
\hline Blyvooruitzicht & Oberholzer & Turffontein & 56.1 & 1937 & 1943 \\
\hline Doornfontein & Turffontein & Oberholzer & 10.8 & 1947 & 1953 \\
\hline
\end{tabular}

is, therefore, unsurprising to read in the Minutes of the following meeting that Professor Harmse 'had indicated, however, that the soil in the area was not as promising as had been expected' (Rafferty, 1977b). The pedologists, unfortunately, do not appear to have concerned themselves with the concepts of 'fertility', or 'productivity' as these are functions of management. They focused on the descriptive criteria, such as 'forms' and 'series', used to classify the soils.

It should be noted that the concern about the future of the area was amplified when it was realised that the Bank Compartment, considered by Jordaan et al. (1960) to be too large to de-water, was in fact not inviolate. On 26 October 1968 the 'big boy fault' ruptured through underground mining operations at West Driefontein GM, which allowed groundwater from the Bank Compartment to flow into the adjacent (de-watered) Oberholzer Compartment. As a result the Bank Eye (average flow $48 \mathrm{M} \ell / \mathrm{d}$ ) ceased flowing within $4 \mathrm{~d}$. When hydraulic pressure plugs in the Bank Dyke were finally installed on 18 November, 1968 after a heroic battle to save the then richest mine in the world from being irretrievably lost, the water table at the pumping shaft (No. 4 Shaft) was restored within 3 weeks (10 December, 1968). After a further 3 weeks the Bank Eye started flowing again (Schwartz and Midgley, 1975).

The pre-AIDS Potgieter Report (Potgieter, 1978), an apparent extension of this concern, was a comprehensive investigation. The physical, demographic, social and economic aspects were investigated as well as land use, infrastructure and administration. The correspondence between the FWRDWA and Prof. Potgieter (Van Rensburg, 1980a; b) shows that the mining industry took exception to the view of Potgieter '... that attention should be given to the possible amendment of the constitutional basis (sic) of the Far West Rand Dolomitic Water Association to make provision for liability for indirect damage caused by de-watering.' The FWRDWA was 'most perturbed by what appeared to be the unwarranted manner in which your Sub-Committee is being used in attempts to serve certain vested interests in the West Wits region.' Potgieter was warned that although the FWRDWA was instrumental in starting the planning initiative, it would seriously consider withdrawing 'if the matter was pursued by the West Wits Regional Planning Committee.' The impression this correspondence leaves is that the vested interests of the mining industry were an overriding foregone conclusion and that if the matter was not pursued to the liking of the FWRDWA members, the initiative would be abandoned.

It would appear that Potgieter decided to play by the FWRDWA rules, as a symposium held on the subject in 1982 (West Wits Regional Planning Committee, 1982) was followed by some Guide Plan Proposals (Potgieter, 1984) and sub-investigations. A comprehensive thesis by Schoeman (1986) deals with the change in function of mining towns and Van Wyk \& Louw Ing. (1993) was commissioned to study the regional water supply on behalf of the West Rand Regional Services Board, and produced a report on the anticipated future water requirements of the area. Later Van Eeden (1997) presented a case history on 'Carletonville's battle for economic survival'. The point made was that: 'a lack of a firm economic substitute for the gold mines ... is an issue without clear directions or programmes'.

Nearly 20 years later and after a number of organisations had been involved in 'planning for the future', nothing seemed to have changed. The Merafong City Local Municipality instructed UE Development Economists to undertake a 'regeneration study' on its behalf (UE Development Economists, 2005). This, on a more limited scale, was largely a repetition of the 1978 efforts of the West Wits Line Regional Planning Committee. Despite this effort, little has changed. Agriculture, for example, which is not mining-dependent and for which substantial local development potential exists, remains dormant. There is little to show for the expenditure and effort, as most, if not all, of the Regional and Local Government agricultural initiatives in the area so far have failed. The few efforts at developing community-driven agricultural projects appear to have been abandoned. The impression left by a succession of new initiatives is that it is all about the appointment of committees and not about the implementation of recommendations.

\section{Conclusions}

History is replete with examples where those who ignore the experiences of the past are doomed to repeat its mistakes. The lessons to be learnt from the knowledge accumulated on the FWR are:

- Politics and industry are self-serving: one is driven by votes, the other by profit. Both are apparently devoid of any social conscience where the acquisition of votes, or the generation of profit are not part of the end-game.

- Many 'good intentions' seem to have fallen by the wayside

- Most predictions of matters crucial for post-mining development have proved to be inaccurate, unreliable and, at best, are only 'guestimates'. The experienced degree of deviation between predictions and reality does, however, provide a $1^{\text {st }}$ order approximation of the ranges of uncertainty to be expected for all further attempts to forecast long-term processes in mining environments. In view of the recently-extended lifespans of mines of another 4 or 5 
decades, this lesson is particularly applicable to any study conducted on the FWR area.

- A major threat to establishing a sound basis for designing postmining scenarios appears to be the loss of institutional memory which has been experienced, which apparently affects all of the stakeholders involved. This includes, for example, government departments which currently act as though the adverse effects of mining in the area, such as widespread uranium pollution, have nothing to do with their policy in the past and which have even attempted to dissolve long-standing committees such as the SCTC which could counterbalance the loss of local expertise and institutional memory.

- With large-scale restructuring following political changes in the recent past and associated loss of expertise, as well as currently experienced exorbitant rates of staff turnover in many departments, the loss of 'institutional memory' on government's side may actually have reached proportions warranting the use of the term 'institutional amnesia'. However, with frequent changes of ownership, personnel and management, as well as insufficient facilities to preserve and archive data, documents and the knowledge gained, this same argument, to a large extent, also applies to the mining industry, which generally does not suffer from a lack of resources.

- It is, therefore, suggested that suitable efforts be made to counteract the further erosion of the existing knowledge base by structured attempts to retrieve and archive data as well as to preserve the knowledge of experts, which in 10 or 20 years' time may no longer be available to be consulted. One possible means to achieve the latter may be to encourage role players and eyewitnesses to place their experiences on record, as is the case in this paper.

- The community, in its own interest, needs to be informed, so as to be in a position to evaluate reports and recommendations and make informed decisions

- There is a lack of motivation on behalf of the local communities to take up any initiative, even if this is in their own best interests, and appear to be satisfied to survive in misery, as long as their fate can be blamed on the inequities of the past. Achieving positive future change will depend on overcoming this 'victim' mentality.

\section{References}

DART RA (1954) Africa's Place in the Human Story. SABC Publication. SABC, Auckland Park, Johannesburg.

ENSLIN JF (1963) Notes of Meeting with Minister of Mines, 24 October. Private collection of EJ Stoch, Welverdiend (unpublished)

ENSLIN JF, KENT LE, HAVEMAN AR, NEETHLING JC, CABLE WH, JORDAAN JM and KRIEL JP (1958) Second Interim Report of the Inter-Departmental Committee; 28 October 1958. Private collection of EJ Stoch, Welverdiend (unpublished).

HAAK JFW (1964) Letter to President of the Gold Producers Committee, 25 November 1964. Private collection of EJ Stoch, Welverdiend (unpublished).

JORDAAN JM, ENSLIN JF, KRIEL JP, HAVEMANN AR, KENT LE and CABLE WH (1960) Finale Verslag van die Tussendepartementele Komitee insake Dolomitiese Mynwater. Verre Wes-Rand. November 1960. Department of Water Affairs, Pretoria (unpublished).

MAUCH C (1872) Travels in the Transvaal and Rhodesia, 1865-1872. National Archive, Zimbabwe.

POTGIETER FJ (1978) West Wits Line Regional Planning Scheme Planning for the Future. Department of Planning, Potchefstroom University, 4 July 1978. Private collection of EJ Stoch, Welverdiend (unpublished).
POTGIETER FJ (1984) Guide PLAN. Proposals submitted to West Wits Regional Development Association. Institute for Regional Planning, Potchefstroom University vir Christian Higher Education, Potchefstroom. Private collection of EJ Stoch, Welverdiend (unpublished).

RAFFERTY L (1977a) Minutes of the Inaugural Meeting of the Steering Committee of the West Wits Line Regional Planning Scheme, 10 February 1977. Private collection of EJ Stoch, Welverdiend (unpublished).

RAFFERTY L (1977b) Minutes of the $2^{\text {nd }}$ Meeting of the Steering Committee of the West Wits Line Regional Planning Scheme, 13 April 1977. Private collection of EJ Stoch, Welverdiend (unpublished)

RAMSDEN HT (1985) The Status, Powers and Duties of the Rand Water Board - Legal History and Analysis: Doctoral Thesis, University of the Witwatersrand, Johannesburg (unpublished).

SCHOEMAN CB (1986) Die Beplanningsimplikasies van die Proses van Funksieverandering by Myndorpe met Spesiale Verwysing na die Witwatersrand. Ph. D. Thesis, Potchefstroom University for Christian Higher Education, Potchefstroom (unpublished).

SCHWARTZ HI and MIDGLEY DC (1975) Evaluation of geo-hydrologic constants of the Far West Rand dolomitic formations: Civ. Eng. S. Afr. 17 (2) 31-36.

STEERING COMMITTEE (1983) Steering Committee Minutes. Private collection of EJ Stoch, Welverdiend (unpublished).

STOCH EJ (1976) Soil Classification, with Particular Reference to South Africa. M.Sc. Thesis, University of Pretoria, Pretoria (unpublished).

SWART CJU, JAMES AR, KLEYWEGT RJ and STOCH EJ (2003) The future of the dolomitic springs after mine closure on the Far West Rand, Gauteng, RSA. Environ. Geol. 44 751-770.

UE DEVELOPMENT ECONOMISTS (2005) Merafong Local Municipality - Local Economic Regeneration Study. July 2005, Carletonville (unpublished).

VAN EEDEN E (1997) So long, gold mines, long live industries? A case study of Carletonville's battle for economic survival. Econ. Hist. Soc. S. Afr. 12 103-127.

VAN RENSBURG PWJ (1980a) FWRDWA letter to Prof. FJ Potgieter, in his personal capacity. Private collection of EJ Stoch, Welverdiend (unpublished).

VAN RENSBURG PWJ (1980b) FWRDWA letter to Prof. FJ Potgieter, as Chairman, private collection of EJ Stoch, Welverdiend (unpublished).

VAN WYK \& LOUW ING (1993) Wesrand Streekdiensteraad: Strategiese Waterbenutingsondersoek: Volumes 1 to 11. Private collection of EJ Stoch, Welverdiend (unpublished).

WESSELS JW, STRANGE WL, RISSIK J, NESER JA, ARMSTRONG BHO, ENSLIN JF, KENT LE and HAVEMANN A (1905) Inter-Colonial Irrigation Commission, Interim Report. Private collection of EJ Stoch, Welverdiend (unpublished).

WEST WITS REGIONAL PLANNING COMMITTEE (1982) Strategy for the Future Guide Plan Proposals submitted to West Wits Regional Development Association. Institute for Regional Planning, symposium, Potchefstroom University for Christian Higher Education. Private collection of EJ Stoch, Welverdiend (unpublished).

WINDE F, STOCH EJ and ERASMUS E (2006) Identification and quantification of water ingress into mine voids of the West Rand and Far West Rand goldfields (Witwatersrand basin) with a view to long-term sustainable reduction thereof. Final Report to Council for Geocience, Project No. 5512, Pretoria (unpublished). $261 \mathrm{pp}$.

WINDE F and STOCH EJ (2010a) Threats and opportunities for postclosure development in dolomitic gold mining areas of the West Rand and Far West Rand (South Africa) - a hydraulic view. Part 1: Mining legacy and future threats. Water SA 36 (1) 69-74.

WINDE F and STOCH EJ (2010b) Threats and opportunities for postclosure development in dolomitic gold mining areas of the West Rand and Far West Rand (South Africa) - a hydraulic view. Part 2: Opportunities. Water $S A 36$ (1) 75-82. 